\title{
FMR1 fully expanded mutation with minimal methylation in a high functioning fragile $\mathrm{X}$ male
}

\author{
Zhimin Wang, Annette K Taylor, Julia A Bridge
}

\begin{abstract}
Cytogenetic and molecular genetic analysis of a peripheral blood sample from a 31 year old, non-mentally retarded male with a family history of fragile $X$ syndrome showed unexpected results. Nine percent of cells evaluated cytogenetically expressed a fragile $X$ chromosome and molecular examination of the FMR1 gene showed a highly unusual pattern defined as a minimally methylated fully expanded mutation. This case illustrates the need to recognise exceptional variations of fragile $\mathbf{X}$ syndrome mutations.

( $($ Med Genet 1996;33:376-378)
\end{abstract}

Key words: fragile X syndrome; FMR1 gene; methylation.

Fragile $\mathrm{X}$ syndrome is the most common cause of inherited mental retardation, occurring in one in every 1250 males and one in every 2000 females. ${ }^{1-4}$ Males affected with fragile X syndrome classically show the following: mental retardation; behavioural problems such as hyperactivity; physical features such as large, protruding ears, long, narrow face, and macroorchidism; cytogenetic evidence of Xq27.3 fragility; and expansion of the CGG trinucleotide repeat at the $5^{\prime}$ end of the fragile $\mathrm{X}$ mental retardation-1 (FMR1) gene with accompanying hypermethylation of the $\mathrm{CpG}$ island upstream of the gene. ${ }^{5-9}$ Recently, however, a few males with normal or borderline IQs, some physical and behavioural characteristics of fragile X syndrome, and molecular genetic (with or without cytogenetic) evidence of fragile X syndrome have been described. ${ }^{10-12}$ The majority of these so-called "high functioning fragile X males" exhibit a full mutation with less than $100 \%$ methylation or are mosaic for a premutation (CGG repeat number between 50 and 200, unmethylated) and a full mutation range ( $>200$ repeats with methylation). These males are different from normal transmitting males ${ }^{13}$ who carry a premutation only and are clinically unaffected. It has been speculated that production of some FMR1 protein is responsible for the milder manifestation of fragile $\mathrm{X}$ syndrome in the high functioning fragile $\mathrm{X}$ males. In a study of males with variant methylation of full mutations, all males with less than $10 \%$ methylation (five cases) had a non-retarded (IQ>70) phenotype and were shown to produce detectable FMR1 protein. ${ }^{14}$

In this study, an extremely rare molecular genetic pattern of a full mutation with minimal methylation is described. We emphasise the importance of recognising this exceptional FMR1 DNA pattern and its clinical relevance.

\section{Case report}

The patient, a 31 year old white male, was referred to the University of Nebraska Medical Center because of a family history of fragile $\mathrm{X}$ syndrome. The patient's sister and mother are both known to be premutation carriers as shown by molecular diagnostic testing and the sister's two sons are mentally retarded and express the typical fragile site on the $\mathrm{X}$ chromosome cytogenetically in a high percentage of cells. Additionally, both nephews have physical features characteristic of fragile $\mathrm{X}$ syndrome. Molecular evaluation of the FMR1 gene in the patient's father showed no abnormalities. The patient has no other sibs and other family members have refused testing.

The patient is a high school graduate and attended college with satisfactory grades for approximately two years. Reportedly, however, certain subjects such as mathematics were difficult for him. He declined IQ testing. Subsequent to his college experience, the patient abused alcohol for four years, received treatment, and has had no problems with alcohol for the past seven years. His mother reports that he was a quiet child and did not suffer from hyperactivity or other behavioural problems. He and his sister have both had problems with depression. Currently, he works as a parole officer in another state.

Physically, the patient has a long, narrow face, slightly protruding ears, and flat feet. He does not have a high arched palate, hyperextensible metacarpophalangeal joints, double jointed thumbs, hand callus, single palmar crease, or heart murmer or click. In summary, the patient has a few physical features characteristic of fragile $\mathrm{X}$ syndrome but based on a short interview does not appear to be affected cognitively or behaviourally.

\section{Materials and methods}

CYTOGENETIC ANALYSIS

Cytogenetic analysis was performed by adding $0.5 \mathrm{ml}$ sodium heparinised whole blood and $0.2 \mathrm{ml}$ of phytohaemagglutinin (GIBCO, Grand Island, NY) to three separate culture media preparations: medium 199 without folic acid at $\mathrm{pH} 7 \cdot 8$, modified RPMI 1640 without folic acid at $\mathrm{pH} 7 \cdot 8$, and RPMI 1640 at $\mathrm{pH}$ $7 \cdot 4$ (with $0.01 \mathrm{mg} / 1 \mathrm{FUdR}$ added 24 hours before harvest). Standard culture and harvest procedures were performed. Twenty metaphase 
cells were fully karyotyped and 150 evaluated for the fragile $\mathrm{X}$ site.

MOLECULAR ANALYSIS

Molecular evaluation of the FMR1 gene was performed by Southern blot hybridisation using a double digest and the StB12.3 FMR1 genomic probe. ${ }^{15}$ The double digest with EcoRI and EagI methylation sensitive restriction endonucleases (New England Biolabs, Beverly, MA) permitted examination of both the size of the CGG trinucleotide repeat and the methylation status of the $\mathrm{CpG}$ island $5^{\prime}$ of the gene. ${ }^{16}$

Briefly, genomic DNA from $5 \mathrm{ml}$ of the whole blood collected in an EDTA tube was isolated. Following an overnight digest of a $10 \mu \mathrm{g}$ DNA sample with $E c o$ RI and EagI, the DNA sample was fractionated by $0.8 \%$ agarose gel electrophoresis on $0.5 \times \mathrm{TBE}$ buffer and transferred to a nylon membrane for Southern blot analysis. Prehybridisation and hybridisation were carried out for six and 18 hours respectively at $42^{\circ} \mathrm{C}$ in $50 \%$ formamide, $6 \times \mathrm{SSC}, 5 \times$ Denhart's, $0 \cdot 1 \% \mathrm{SDS}, 50 \mu \mathrm{g} / \mathrm{ml}$ human placenta DNA, and $100 \mu \mathrm{g} / \mathrm{ml}$ herring sperm DNA (Boehringer Mannheim 223 646, Indianapolis, IN). The StB12.3 probe was labelled using a random primer DNA labelling system (GIBCO BRL 18187-013) according to the manufacturer's directions. Following washing, the filter was exposed to Kodak X-OMAT $x$ ray film at $-85^{\circ} \mathrm{C}$ for one to three days with intensifying screens.

Initial examination of this patient's sample using standard laboratory procedures (as described above, with an 18 hour agarose gel electrophoresis) showed no apparent bands or smears. We determined that non-degraded DNA was indeed present in the lane by using another X chromosome probe (DXS100 located at Xq25), and subsequent electrophoresis in $1 \%$ agarose gel for the shortened time of eight hours led to the detection of a smear in the unmethylated region.

In the Denver laboratory, a thorough examination of methylation status was conducted by Southern blot analysis using EcoRI/NruI double digests and $1 \%$ agarose gel electrophoresis in Tris acetate (TAE) buffer. The NruI site is near that of EagI and has been shown to give the same results as EagI. ${ }^{17}$ Using this method, a long smear was seen in the unmethylated ( $N r u I$ digested) region above $2.8 \mathrm{~kb}$ and also a faint signal above $5 \cdot 2 \mathrm{~kb}$ (methylated). Digital sizing (DNAStar Inc) allowed estimates of CGG repeat number to be made (approximate CGG number $=$ (base pairs/ $3)+30$ ). The signal intensity of the methylated and unmethylated signals was accurately quantitated by phosphorimaging. The membrane was exposed to a phosphor screen for 12 hours and the screen was scanned in a phosphorImager (Molecular Dynamics Inc, Sunnyvale, CA). ImageQuant software was used to integrate the volume of signals. The ratio of (methylated)/(methylated plus unmethylated) signals was calculated. This provides an estimate of the percent methylation of the FMR1

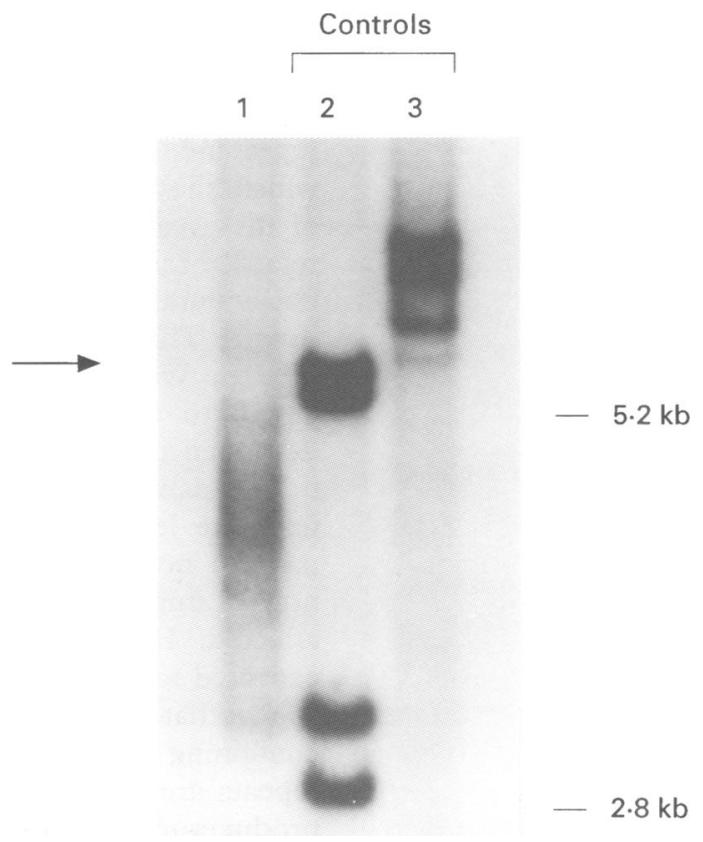

Southern blot analysis of DNA from the patient (lane 1), a female premutation carrier control (lane 2, 108 CGG repeats), and a male full mutation control (lane 3). Genomic DNA was digested with EcoRI and NruI, separated by $1 \%$ agarose gel electrophoresis, blotted, and hybridised with FMR1 probe, StB12.3. The positions of the $2 \cdot 8 \mathrm{~kb}$ normal unmethylated (active $X$ ) and the $5 \cdot 2 \mathrm{~kb}$ normal methylated (inactive X) FMR1 bands are indicated. The arrow indicates the position of the faint methylated portion of the patient's mutant FMR1.

gene, reflecting the percentage of cells carrying the gene in methylated form.

\section{Results}

Cytogenetic analysis yielded expression of the fragile $\mathrm{X}$ site in $9 \%$ (14 of 159) metaphase cells. Southern blot analysis with the StB12.3 probe (figure) showed a long smear above $2 \cdot 8 \mathrm{~kb}$ representing unmethylated FMR1 genes with CGG repeat number ranging from approximately 131 to 839 (most intense signal centred at 557 repeats) and a faint signal above $5 \cdot 2 \mathrm{~kb}$ (methylated) with an estimated CGG repeat number of 224 (see arrow). Through phosphorimaging it was calculated that the FMR1 gene is $3.7 \%$ methylated. Therefore, this is a rare fully expanded mutation with minimal methylation.

\section{Discussion}

The frequency of expression of the fragile $\mathrm{X}$ chromosome cytogenetically in affected males is distributed over a wide range, 2 to $50 \%$, and rarely if ever has been described in males of normal mentality with a positive family history. ${ }^{18}$ In the present case, the fragile $\mathrm{X}$ chromosome was seen in $9 \%$ of metaphase cells evaluated (14/150). This result would be interpreted as typical of a fragile $\mathrm{X}$ male. This case is not, however, typical, since the subject is not retarded and the methylation status of the mutant gene is unusual.

Molecular examination of the fragile X mutation in the present case showed a fully expanded 
mutation with $<5 \%$ methylation and widely heterogeneous size of the unmethylated FMR1 gene population. To our knowledge, this case represents one of fewer than 10 documented which show this mutation pattern. ${ }^{1011214}$ All of these cases are males with IQs above the retarded range and a few to several physical or behavioural characteristics of fragile $\mathrm{X}$ syndrome. The level of FMR1 protein, as measured by Western blot analysis, was shown to be 10 to $60 \%$ of normal in the previously described males with minimal methylation of fully expanded mutations. ${ }^{14}$ We did not evaluate the level of the FMR1 protein in this patient; however, a level of at least $50 \%$ of normal might be possible as he is very mildly affected. However, the levels would not be expected to approach $100 \%$, since it has been shown that though unmethylated FMR1 genes containing more than approximately 200 CGG repeats are efficiently transcribed, their RNA products are not translated. ${ }^{19} \mathrm{~A}$ significant proportion of our patient's unmethylated FMR1 contained more than 200 repeats.

The percent cytogenetic expression of the fragile $\mathrm{X}$ site tends to be depressed for full mutations with minimal methylation as compared to full mutations with $100 \%$ methylation. ${ }^{10}$ All patients so far identified with $<5 \%$ methylation of full mutations have had less than $10 \%$ fragile $\mathrm{X}$ expression, ranging from $0 \%$ to $9 \%$ (the $9 \%$ being from our patient). The cytogenetic test will therefore miss diagnosing fragile $\mathrm{X}$ syndrome in some high functioning fragile $\mathrm{X}$ males. The FMR1 DNA test is superior, not only in its accuracy, but also in its capacity to provide information about CGG repeat number and methylation status.

Genetic counselling is an important aspect of care for all fragile $\mathrm{X}$ patients and their families. Counselling about the risk to future offspring of our patient may be similar to that for males carrying a fragile X premutation (normal transmitting males). All males with an FMR1 mutation, whether a premutation or a full mutation, carry a premutation in their sperm. ${ }^{2021}$ Because the FMR1 gene is on the $\mathrm{X}$ chromosome, the mutation will be passed on to all daughters and no sons. The daughters will be unaffected with fragile $\mathrm{X}$, but will be at risk for having offspring with fragile $\mathrm{X}$ syndrome.

1 Gustavson G, Bloomquist HK, Holmgren G. Prevalence of the fragile-X syndrome in mentally retarded children in a Swedish county. Am $\mathcal{F}$ Med Genet 1986;23:581-7.

2 Lubs HA. A marker X-chromosome. Am f Hum Genet 1969; 21:231-44.

3 Sutherland GR. Fragile sites on human chromosomes: demonstration of their dependence on the type of tissue culture medium. Science 1977;197:256-66.

4 Webb T, Bundey S, Thake J, Todd A. The frequency of the fragile $\mathrm{X}$ chromosome among schoolchildren in of the fragile $\mathrm{X}$ chromosomet 1986;23:396-9.

5 Bell MV, Hirst MC, Nakahori Y, et al. Physical mapping across the fragile $\mathrm{X}$ : hypermethylation and clinical exacross the fragile X: hypermethylation and clinical ex-
pression of the fragile X syndrome. Cell 1991;64:861-6.

pression of the fragile $X$ syndrome. Cell 1991;64:861-6. Hagerman RJ. Physical and behavioural phenotype. In:
Hagerman RJ, Cronister-Silverman A, eds. Fragile X syndrome, diagnosis, treatment and research. Baltimore: The Johns Hopkins University Press, 1991: 89-145.

7 Kremer EJ, Pritchard M, Lynch M, et al. Mapping of DNA instability at the fragile $\mathrm{X}$ to a trinucleotide repeat sequence $\mathrm{p}(\mathrm{CGG})$, Science 1991;252:1711-14.

8 Verkerk, AJMH, Pieretti $M$, Sutcliffe JS, et al. Identification of a gene (FMR-1) containing a CGG repeat coincident with a breakpoint cluster region exhibiting length variation in fragile X syndrome. Cell 1991;65:905-14.

9 Yu S, Pritchard M, Kremer E, et al. Fragile X genotype characterized by an unstable region of DNA. Science 1991; 252:1179-81.

10 Hagerman RJ, Hull CE, Safanda JF, et al. High functioning fragile $\mathrm{X}$ males: demonstration of an unmethylated fully expanded FMR-1 mutation associated with protein expression. Am $\mathcal{F}$ Med Genet 1994;51:298-308.

11 McConkie-Rosell A, Lachewicz AM. Spiridigliozzi GA, et al. Evidence that methylation of the FMR1 locus is responsible for variable phenotypic expression of the fragile $\mathrm{X}$ syndrome. Am F Med Genet 1993;53:800-9.

12 Merenstein S, Shyu V, Sobesky WE, Staley L, Taylor AK, Hagerman RJ. Fragile X in a male with normal IQ and learning disabilities. I Am Acad Child Adolesc Psychiatry 1994;33:1316-21.

13 Sherman SL, Jacobs PA, Morton NE, et al. Further segregation analysis of the fragile $\mathrm{X}$ syndrome with special reference to transmitting males. Hum Genet 1985;69:28999.

14 Taylor AK, Safanda JF, Lugenbeel KA, Nelson DL, Hagerman RJ. Molecular and phenotypic studies of fragile X males with variant methylation of the FMR1 gene reveal males with variant methylation of the FMR1 gene reveal
that the degree of methylation influences clinical severity. that the degree of methylation in
Am f Hum Genet 1944;51:A18.

15 Oberlé I, Rousseau F, Heitz D, et al. Instability of a 550base pair DNA fragment and abnormal methylation in fragile X syndrome. Science 1991;252:1097-102.

16 Rousseau F, Heitz D, Biancalana V, et al. Direct diagnosis by DNA analysis of the fragile $X$ syndrome of mental retardation. $N$ Engl f Med 1991;325:1673-81.

17 Taylor AK, Safanda JF, Fall L, et al. Molecular predictors of cognitive involvement in female carriers of fragile $\mathrm{X}$ syndrome. $\mathcal{F} A M A$ 1994;271:507-14.

18 Jacky P. Cytogenetics. In: Hagerman RJ, Cronister-Silverman $\mathrm{A}$, eds. Fragile $X$ syndrome, diagnosis, treatment and research. Baltimore: Johns Hopkins University Press, 1991: research. 145 .

19 Warren ST, Zhang F, Lokey LK, et al. Influence of CGG repeat length upon FMRI transcription and translation. repeat length upon FMR1 tran

20 Reyniers E, Vits L, Boulle KD, et al. The full mutation in the FMR-1 gene of male fragile $X$ patients is absent in their sperm. Nature Genet 1993;4:143-6.

21 Wöhrle D, Henning I, Vogel W, Steinbach P. Mitotic stability of fragile $\mathrm{X}$ mutations in differentiated cells indicates early post-conceptinal trinucleotide repeat expansion. Nature Genet 1993;4:140-2. 